\title{
The Quadrants of Shari'a: The Here and Hereafter as Constitutive of Islamic Law
}

\author{
Anver Emon \\ Version Publisher's Version \\ Citation Emon, Anver M., The Quadrants of Shari'a: The Here and Hereafter as \\ (published version) Constitutive of Islamic Law (February 9, 2011). ROADS TO \\ PARADISE, Todd Lawson, Sebastian Geunther, eds., Brill \\ Publications, 2011. \\ Publisher's Statement This is the peer reviewed version of the following article: "Anver \\ Emon, The Quadrants of Shari'a: The Here and Hereafter as \\ Constitutive of Islamic Law (February 9, 2011). ROADS TO \\ PARADISE, Todd Lawson, Sebastian Geunther, eds., Brill \\ Publications, 2011", which has been published in final form at \\ https://doi.org/10.1163/9789004333154_053. This article may be \\ used for non-commercial purposes in accordance with Brill \\ Publishing \\ Terms and Conditions for Self-Archiving.
}

How to cite TSpace items

Always cite the published version, so the author(s) will receive recognition through services that track citation counts, e.g. Scopus. If you need to cite the page number of the author manuscript from TSpace because you cannot access the published version, then cite the TSpace version in addition to the published version using the permanent URI (handle) found on the record page.

This article was made openly accessible by $U$ of $T$ Faculty. Please tell us how this access benefits you. Your story matters. 


\title{
The Quadrants of Sharía: The Here and Hereafter as Constitutive of Islamic Law
}

\author{
Anver M. Emon*
}

The relationship between law and morality is a topic of considerable debate in Anglo-American legal philosophy. That debate is often identified with the exchange between H.L.A. Hart and Lord Patrick Devlin in the latter half of the twentieth century. The debate started when a 1957 committee recommended that consensual sexual activity between men in private should be decriminalized. This recommendation met with sharp criticism from Lord Devlin. As Peter Cane states,

Although Devlin did not express it as straightforwardly as he might have, his basic point was that the criminal law was not (just) for the protection of individuals but also for the protection of society - 'the institutions and the community of ideas, political and moral, without which people cannot live together.'1

* The Islamic legal research herein was inspired by my work with Professor Denise Spellberg, of the University of Texas at Austin, a mentor, colleague, and friend, to whom I owe many thanks. The author also wishes to thank Sebastian Günther and Todd Lawson for their generous support and encouragement of this article, as well as Meghan Clark and Aleatha Cox for their assistance in editing the article. This article benefited greatly from all of the above; all errors and limitations that remain are the author's responsibility. The quadrants model offered herein was first presented at a graduate seminar at the Faculty of Law on Law, Religion, and the Public Sphere, which I co-taught with Jennifer Nedelsky. The debate around the quadrants model, from both the students in that seminar and from Professor Nedelsky helped make this a better article. The initial inspiration for this article came from a grant awarded to myself and my colleague Robert Gibbs from Canada's Social Science and Humanities Research Council, and which supported our research on the nature of legal reasoning in Islamic and Jewish law. The author gratefully acknowledges the support of the SSHRC.

1 Cane, Taking law seriously 22, quoting Patrick Devlin, The enforcement of morals (Oxford 1965), 22. 
Hart rejected Devlin's assertion, and instead argued that the scope of the criminal law was defined by the harm principle, which seeks to prevent harm to others. ${ }^{2} \mathrm{He}$ outright repudiated the view that legal enforcement of widely held moral norms is justified. This is a deeply contested debate, and one that remains a topic of considerable scholarship. ${ }^{3}$ This is not the place to address the nuances of that debate. But that issue in contemporary legal philosophy certainly forms a backdrop to this essay.

The distinction between law and morality seems to be in the minds of many who write about Islamic law and explain its scope of regulation to an audience unfamiliar with the tradition. ${ }^{4}$ In doing so, though, they rely on that distinction to illustrate the limits and inefficiency of the Islamic legal tradition. For instance, Wael Hallaq argues that the meaning of 'law' is so substantially founded upon assumptions about the state and its institutional powers that any characterization of $\operatorname{sharî}^{-} a$ as "law" will render it a failed system. As evidence, he refers to the "routine and widespread pronouncement, usually used to introduce Islamic law to the uninitiated, namely, that the Sharīa does not distinguish between law and morality." For Hallaq, the view that sharía suffers no distinction between law and morality is relied upon as one of the factors that "rendered [the sharīa] inefficient and paralyzed." unity between law and morality in the $\operatorname{sharit}^{-} a$, however, is applauded as yet further evidence of the moral superiority of Islam over other legal systems; these systems, they say, have stripped law of moral content. ${ }^{7}$ Between these two views of Islamic law lies a third, which emphasizes that all rules in Islamic law are categorized pursuant to the al-ahkām al-khamsa, or the five categories of legal value: obligatory (wäjib), recommended (mustahabb), permitted (haläl), reprehensible (makrūh), and prohibited (harām/maḩzūr). This typology of rules is used to show that Islamic law has its own approach to distinguishing between 'law' and 'morality': the obligatory and prohibited are "law" in the modern sense, while the recommended and reprehensible categories are extra-legal, falling into the realm of morality. ${ }^{8}$

2 Cane, Taking law seriously 22.

3 For other views on the debate, see Dworkin, Enforcement of morals 986-1005.

4 Kamali, Shariah law 43-4; Coulson, Conflicts and tensions 77-95, who begins his discussion by reference to Hart's discussion of law and morality, where he responds to Devlin.

5 Hallaq, Sharīa 2.

6 Ibid.

7 Abu-Saud, Concept of Islam 118-20; Moaddel and Talattof, Contemporary debates in Islam 197-206 (presenting Sayyid Qutb's Islam and culture, excerpted from his Milestones).

8 Kamali, Principles 44-6; Kamali, Shari'ah law 44; Hallaq, Sharĩa 84-5. Hallaq disagrees with this latter argument, and suggests that Muslim jurists did not distinguish between law and 
Hallaq's apprehension and critique of characterizing Islamic law in terms of the law/morality distinction both challenges the assumptions underlying the meaning of "law," and runs the risk of isolating Islamic law from compelling philosophical debates about law, its limits, and its coercive power. The Hart/ Devlin debate concerned whether and to what extent particular substantive moral norms could be relied upon in the UK legal system, which has its own history and institutional design. Elsewhere, I have written about how premodern Muslim jurists were cognizant about the public good (ḥuqūq Allāh)

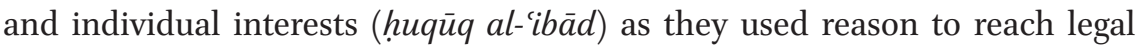
outcomes about substantive doctrine. ${ }^{9}$ In both cases, conceptual dichotomies operate to categorize different types of interests and aspirations that animate the development of law.

Conceptual dichotomies, whether law/morality or ḥuqūq Allāh/ḥuqūq al-iba $\bar{a}$, provide analytic modes of understanding and appreciating the dynamics of the law. And however useful they may be, when employing them, we must remain mindful about how such conceptual dichotomies carry more intellectual baggage than may be duly disclosed. For instance, in Hart and Devlin's debate, at issue was not so much what is law and what is morality, but rather whether the state can legislate general rules of criminal law based on a particular moral outlook. The intelligibility of their debate depends, therefore, on a variety of unstated preconditions, not all of which were historically present in the formative period of Islamic law. Such preconditions might include:

- The existence of a state with centralized legislative and enforcement power;

- A morally pluralistic polity in which all are given equal status;

- A democratically formed state in which the will of the people is accounted for in a legislative process.

Not all of these preconditions map onto the Islamic historical tradition, legal or otherwise. Consequently the stakes for Hart and Devlin may not be easily translatable for the purpose of analyzing pre-modern Islamic law and legal theory. That does not mean that the underlying interests captured by "law" and "morality" cannot be defined or articulated in different ways that take into account the differences posed by competing legal systems. Nor are we constrained by conceptual dichotomies that are borrowed from other traditions. As noted above, the pre-modern Islamic conceptual dichotomy of huqūq

morality. Instead, he queries the modern division between law and morality, which he suggests is neither normative nor natural in the course of human history.

9 Emon, Huqūuq Allāh and huqūuq al-ibād. 
Allāh and huqūq al-'ibād offers one site of examination. Another site, which is the topic of this essay, concerns the role of the here and hereafter in legal reasoning.

Imagine for a moment each Islamic doctrinal rule occupying a position on an $\mathrm{x}-\mathrm{y}$ graph. The horizontal $\mathrm{x}$ axis reflects the impact and significance of a given doctrinal rule on individuals living in society together. The vertical y axis reflects the relationship of the doctrinal rule to the will of God. Any doctrinal rule, therefore, is plotted on the $x-y$ graph in light of considerations about the social significance of a given rule of law (the here = al-dunya in Quranic parlance), and its eschatological implications for the believer (the hereafter = al-äkhira). The more the doctrinal rules reflect social considerations, the higher the $x$ value and the lower the y value (although greater than zero). The more the doctrinal rules reflect a concern about God's will and eschatological concerns, the higher the $y$ value and the lower the $\mathrm{x}$ value. Ideally, every rule should be plotted in quadrant $\mathrm{I}$, where the $\mathrm{x}$ and $\mathrm{y}$ values are both positive.

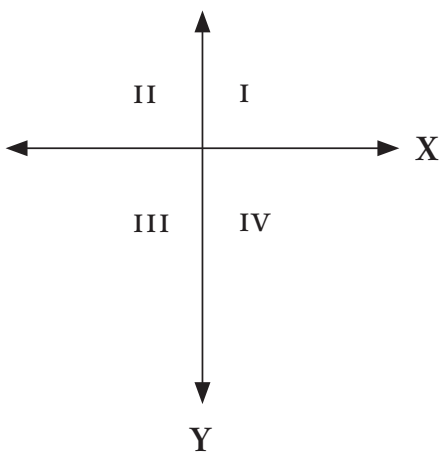

Problems in justification and legitimacy may arise when a doctrinal rule is plotted in quadrants II, III, or IV. For instance, a rule that aspires to fulfill God's will but comes at a certain social cost might have a negative $\mathrm{X}$-value and a positive Y-value, and thus be plotted in quadrant II. A rule that has a positive social value but seems to violate God's desires will have a positive $\mathrm{X}$-value but negative Y-value, and thus fall in quadrant IV. A rule that adversely impacts the social well-being and violates God's will falls into quadrant III. Being mindful of these quadrants, we can imagine a Muslim jurist taking into account both the 'here' and 'hereafter' when considering how to evaluate a particular doctrinal rule, with the goal of ensuring that every doctrinal rule is plotted in quadrant I. In other words, to the extent this collection of essays concerns paradise as a destination, Islamic law in general and the quadrants model in particular emphasize the signs along the way. Rather than being about paradise as 
eschatological destination, this chapter focuses on law in order to reflect on the challenges of the journey itself.

To illustrate and justify the explanatory power of this proposed quadrant model of analysis, this essay addresses different doctrinal issues in the history of Islamic law. In particular, the legal issues discussed revolve around the dog in Islamic law. The dog was a subject of legal debate that moved between concerns about the here and the hereafter. Those concerns were framed in terms of, for example, ritual requirements for prayer, the regulation of the domestic household, and the management of agricultural professions. Although this study focuses on traditions concerning dogs, it is not meant to offer a scholarly treatment of the dog in the Islamic tradition. ${ }^{10}$ Rather this study introduces a conceptual model of analysis, using debates about the dog, to grasp and appreciate how the here and hereafter contribute to Muslim jurists' reasoning about the law.

$\mathbf{1}$

Why the Dog?

The vast number of doctrinal rules about the dog, arguably, are built upon a particular tradition concerning a dog that licked water from a bowl. A hadith, narrated by the companion of the Prophet Muhammad, Abū Hurayra (d. ca. 58 or 59/678), ${ }^{11}$ reads: "The messenger of God...said 'If a dog licks your container, wash it seven times."'12 A second version of this hadith stipulates different numbers for the required washings, ${ }^{13}$ and a third version requires one

10 For studies on the dog in the Islamic tradition, see Abou El Fadl, Lord of the essence 316-30; Abou El Fadl, Dogs in the Islamic tradition 498-500.

11 The fact that Abū Hurayra narrated this hadīth is a point of initial interest. It is relatively well known that Abū Hurayra was fond of cats. His name suggests his favoritism toward that animal (i.e., father of a female kitten). It is reported that he received his kunya, Abū Hurayra, because he found a kitten and carried it in his sleeve. On the other hand, other sources suggest that he may have also owned a farm dog. Al-Dhahabī, Siyar a lām ii, 579; al-Nawawī, Sharh șaḥịh Muslim ix-x, 478, 483 .

12 Al-Nawawī, Sharh șậịh Muslim iii-iv, 174.

13 The Hanafīs rely on a version of the Abū Hurayra hadīth on dogs and water in which the Prophet is reported to have required either three, five, or seven washings. Al-Sarakhsī,

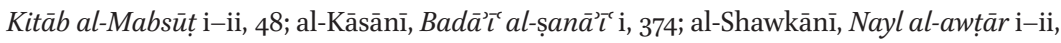
34; Ibn Ḥajar al-'Asqalānī, Fatḥ al-bārī i, 332; al-Mubārakfūrī, Tuhfat al-aḥwadhī 253-4. 
to dump the contents of the container prior to washing it seven times. ${ }^{14} \mathrm{~A}$ fourth version reads as follows: "The messenger of God... said: 'Concerning the purity of your container (țhūrină ahadikum), if a dog licks from it, wash it seven times."'15 Furthermore, some versions of this hadith pose the additional requirement of sprinkling sand or earth in one of the washings. ${ }^{16}$ The use of sand or earth as a cleansing agent both recognizes the purity of the earth for purification purposes, ${ }^{17}$ and renders the dog's impurity something that goes beyond a concern about conventional dirt per se.

At the core of the tradition is a concern about the implication of the dog for the purity of the water in the bowl. The implication of this concern can extend far and wide, based on the multitude of ways impurity can both transfer to other objects and affect human behavior. For instance:

- Can a Muslim use the water a dog licks to perform ritual ablutions?

- How large must the container of water be before concerns about wasting water used for purification arise?

- If the dog is impure, can it be bought and sold in the market?

The potential impact this single tradition could have on a multitude of issues prompted the jurist Ibn Hajar al-'Asqalānī (d. 853/1449) to write: "The discussions on this hadith, and the issues that arise from it, are so widespread that one could write an entire book [about them]."18 The wide array of legal issues the dog raises permits us to examine whether and how the proposed quadrants model of the shari $a$ offers a better approach to understanding the nature of Islamic legal analysis, in contrast to the more dominant model of jurisprudence that posits an analytic dichotomy between law and morality.

14 Al-Nawawī, Sharh șậh Muslim iii-iv, 174. Those who oppose the implications of this addition (i.e., iraqqa) argue that one of the members of the isnād, 'Alī b. Mushīr (d. 189/804), was not a reliable transmitter. However, al-Dhahabī considers him trustworthy. Al-Dhahabī, Siyar a ‘̄àm viii, 484. See also al-Ziriklī, al-A'lām v, 22.

15 Al-Nawawī, Sharh șaḥịh Muslim iii-iv, 175. As will be indicated below, seven is not the only number mentioned on this matter. The Hanafĩs adopt traditions which require three, five, or seven washings. The significance of the number is reflected in how jurists contend with its apparent arbitrariness, which will be discussed below. On the relationship between arbitrariness and rules, see Atiyah and Summers, Form and substance 13.

16 Al-Nawawī, Sharh șaḥh Muslim iii-iv, 175-6. There is a debate as to whether one dusts prior to the seven washings, in the first wash, in the last wash, or somewhere in between. See also Ibn Ḥajar al-'Asqalānī, Fatḥ al-bārī i, 331.

17 Wensinck, Tayammum.

18 Ibn Ḥajar al-'Asqalānī, Fatḥ al-bārī i, 333. 


\section{The Dilemma of the Dog: Limiting the Dangers of the Logical} Extreme

For Muslim jurists, a source text, such as a hadìth, can be applied to diverse situations, not all of which are expressly provided for in the hadīth text. Jurists can analogize (cf. qiyās) between express circumstances in the hadith and the circumstances of a new situation. In doing so, they engage in an act of legal reasoning that seeks to extend the application of a rule to a similar case that warrants the legal extension.

However, the ability to extend a ruling by analogy depends on whether the hadith espousing the initial rule, with its relevant factual circumstances, has a discernible rationale that explains and justifies the legal outcome. Without such a ratio, the hadith may not be extended so easily to new and different situations, given that an analogy with a rational nexus between the given rule and the new circumstance cannot be rendered. But if a ratio is read into the law, such as "those dogs are impure," the ratio could have considerable consequences on social well being.

If jurists render all dogs impure, the consequence of applying the dog-water hadith generally and absolutely might lead to considerable waste, whether of water or any other item a dog might touch or lick. This concern led Mālik b. Anas (d. 179/796) to consider it a grave sin for someone to discard something, which was the sustenance of God and was meant to be of benefit, because a dog licked it. ${ }^{19}$ To require such waste arguably creates perverse incentives against animals, and could even incite violence against them. Traditions from the Prophet about killing dogs, discussed below, play into and further inflame this incentive. ${ }^{20}$

Jurists, well aware of the social costs that might arise if the dog-water hadith were read and applied too broadly, developed different strategies to limit its application. Some jurists believed the tradition was a matter of "worshipful obedience" (ta'abbud), because it relates to the believer's commitment to obey God and seek the fulfillment of His will. Jurists such as al-Shäfi'i held that the dog is impure in its essence. But if the dog is impure in its essence, it could contaminate anything it has contact with. For al-Shāfi'ì, though, this possibility

\footnotetext{
19 Saḥnūn, al-Mudawwana i, 5. See also Ibn Hazm, al-Muḥallā i, 121.

20 There are various animal rights groups in the Muslim world protesting against governments that engage in seasonal killings of stray dogs. See for example, http://www.esma egypt.org/. The Fatimid caliph al-Hākim bi-Amr Allāh is well known for having decreed the execution of dogs on two separate occasions, presumably because their barking annoyed him. Canard, Hākim Bi-Amr Allāh.
} 
is limited because of the absence of any ratio explaining the number of washings. For jurists like al-Shāfi'i, the hadìth on the dog and water proved perplexing because of the apparent arbitrariness of the number of requisite washings. There seems to be no rationale justifying the number of washings, nor is there a necessary rational connection between the number of washings required and the kind of impurity presumed to be in the water or on the bowl. Indeed, if anything, the required number of washings was simply a directive to be obeyed dutifully. Consequently, while al-Shāfi'i considered the dog impure, he read the hadith as requiring strict, worshipful obedience (ta'abbud). In other words, the hadith must be adhered to, but can be extended in very limited circumstances, given the lack of an underlying rationale. For this reason, al-Shāfi'ī remarked that it is inappropriate to use the dog-water hadith to govern other cases when different impurities fall into water. ${ }^{21}$ Hence, although al-Shāfíi considered the dog impure, the legal effect of its impurity is limited to instances involving only a dog. If a dog is part of the legal question, the dog-water tradition will govern, even in situations beyond the impurity of water. But other instances of impurity, in which a dog is not involved, cannot be governed by reference to the dog-water hadìth.

A second interpretive strategy was to read the hadith as being less about the dog per se and more about the removal of impurities (najāsa). On this basis, these jurists extended the rule to apply to other types of impurity, thereby expanding the precedential effect of the dog-water hadith. But in doing so, they had to contend with countervailing issues as well, such as waste. For instance, suppose a dog touches one's clothes or eats solid food from a bowl. Technically these circumstances are not addressed in Abū Hurayra's tradition as noted above. But if we believe the hadith relies on the ratio of impurity, we may want to extend its application to these new situations. Yet if we extend its application, how far must we go before countervailing considerations, such as waste and limited resources, factor into the analysis?

For example, the Ḥanafĩ jurist al-Kāsānī (d. 587/1191) suggested that focusing on the dog itself actually blurs the larger issues at stake. Suppose a dog, after being immersed in water, emerges and shakes the water off its body near a group of people. If the water lands on someone's clothes, does that mean the clothing is impure? If we assume the dog is impure in its essence, then anything it touches becomes impure. But if we separate the impurity from the

21 Al-Shāfíī Umm i, 20. Al-Shāfíī held that the dog-water tradition can be extended to other situations, depending on how one understands what it means to wash. Yet he explicitly considers the dog-water tradition a matter of worshipful obedience. See also al-Māwardī, al-Hāwì l-kabìr i, 308. 
essence of the dog, we can put a break on the slippery slope of imputing pollution to all the dog touches. In other words, we can shift our focus to the impact of the purported impurity on the object of concern. In the example above, al-Kāsānī argues that the issue of impurity has less to do with the dog and more to do with the amount of water that splashes on the clothes. If the amount of water that hits the clothes exceeds the volume and size of a coin (i.e., dirham), the clothes are considered ritually impure and the wearer cannot perform ritual prayers. Anything less entails no impurity. ${ }^{22}$

Similarly, the Mālikī jurist Ibn Rushd al-Jadd (d. 520/1126) held that the tradition applies to the impurities that must be removed. For Ibn Rushd al-Jadd, the reference to the requisite seven washings evokes concerns over the health consequences associated with dogs lapping water, specifically dogs with rabies. ${ }^{23}$ He noted that the Prophet said during an illness, "pour over me seven waterskins (qirab) whose tying ribbons are untied, so that I can attend to the people." ${ }^{24}$ Here, the number seven is associated with medical care, and not any particular impurity. He wrote:

It is necessary to be cautious of the dog's drinking or eating, and of using the vessel prior to washing it, out of fear that the dog has rabies. It is in the case of rabies, which appears in [the dog's] saliva looking like poison harmful to the body, that the Prophet's command, namely to wash the vessel from which the dog laps seven times to guard against illness, becomes applicable... ${ }^{25}$

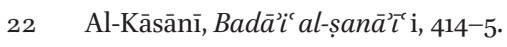

23 Ibn Rushd al-Jadd, al-Muqaddimāt i, go. Not all Mālikīs would have agreed. Abū Bakr b. al-'Arabī (d. 543/1148) said: "[In this case] the number [of washings] is mentioned, and a dusting is included with it. This [process] establishes that it is pure out of worship ('ibādatan), [since] there is no requisite number or use of dust for washing out an impurity." Ibn al-'Arabī, 'Āriḍat al-aḥwadhī ii, 134.

24 Ibn Rushd al-Jadd, al-Muqaddimāt i, 90-1.

25 Ibid. This same sort of rationale exists in rules regulating dog ownership in cities across the United States. For instance, Austin, Texas City Ordinance contains a provision prohibiting the ownership of dogs that have not been vaccinated for rabies. Austin City Ordinance $33^{-3}-25(A)$ provides: "No person shall own, keep or harbor within the city any dog or cat over the age of four months unless such dog or cat has a current rabies vaccination. The dog or cat shall be revaccinated before the expiration of the first and each subsequent current vaccination as provided by state law." Further, the City has gone so far as to authorize the city's Health Authority to sponsor rabies-vaccination clinics. Austin City, $3-3-26$. 
For Ibn Rushd al-Jadd, the number offers an insight into the rationale of the rule. He was unconvinced that the rule is simply about worshipful obedience; if it were, then the rule could not be extended or analogized to other situations since it lacks a ratio legis ('illa) that provides an objective basis for reasoned analysis. While it may be tempting to consider the hadith as a rule of worshipful obedience that cannot be extended to other situations, the social reality of impurity, whether associated with the dog or not, would seem to require sufficient flexibility in the norm to extend to new situations. ${ }^{26}$ This is not to suggest, though, that Ibn Rushd al-Jadd disregarded any limits to extending the rule. He was mindful of concerns about waste. So while he generally held that all carnivorous animals (including dogs) contaminate what they lick, whether water or food, ${ }^{27}$ he devised two important exceptions. First, if the water lapped is large in quantity, then it is not rendered impure. The larger the quantity, the more likely it is that the impurity dissipates throughout the water, thus rendering the whole amount suitable for ritual purification. Second, one can only discard food licked by an animal if one is absolutely certain the food is polluted. But in this case, certitude is contingent upon an ancillary inquiry into whether the animal is domesticated or not. If the animal is wild or undomesticated, we can be certain the food is polluted. Otherwise, certainty cannot be established. For Ibn Rushd al-Jadd, the domesticity of the dog operates as a limiting factor on the extension of the hadith to situations that might raise the specter of waste. ${ }^{28}$ By shifting the focus of inquiry to issues such as the nature

26 Ibn Rushd al-Jadd was not compelled by those who argued that the dog-water tradition is purely about worshipful obedience or purely about impurity. He was critical of those who reduced the issue purely to a matter of removing impurity because they could not explain the specific number of washings stipulated in the tradition. But those who view the dogwater tradition as a rule of worshipful obedience seem to preclude concerns about impurity that seem present on the face of the tradition. Taking a middle road between these two positions, Ibn Rushd al-Jadd argued that whatever number of washings purifies the object, those are justified on the basis of removing the impurity. Any additional washing that occurs because of the hadīth is purely worshipful obedience, and nothing else. Ibn Rushd al-Jadd, al-Muqaddimāt i, go.

27 Ibid., i, $87-8$.

28 Ibn Rushd al-Jadd addressed the issue of domesticity of dogs by reference to a different hadìth concerning cats. In this tradition, a man named Abū Qatāda came upon his wife Kabasha while she was filling a container with water so that her husband could ritually purify himself before making prayers. A cat approached her, wanting to drink the water. Kabasha tilted the container so that the cat could lap water from it. Her husband later remarked: "The messenger of God ... said 'The cat is not impure. Rather it is among those 
of impurity, quantity, and domesticity, jurists such as al-Kāsānī and Ibn Rushd al-Jadd utilized complex legal reasoning to alleviate the potential burdens of assuming that the dog is impure.

Importantly, the two different readings of the tradition offer two significant reflections on the axes of analysis that operate within Islamic legal analysis. First, the view that the hadith is ta'abbud, or worship-centric, emphasizes the eschatological significance implicit in any instance of Islamic legal reasoning. One cannot ignore the importance of obedience to God (and hence of eschatology) as part of the Islamic legal calculus. Consequently, the quadrants model of analysis accounts for the eschatology of legal analysis along the vertical y axis, which is meant to capture those modes of behavior that are directed solely for the pleasure of God. Second, the view that the dog-water hadith is concerned with impurity but not to the point of waste, reflects the way in which the law cannot ignore, and indeed must account for, the social well-being of individuals living in an organized society. As such, we can account for the social ramifications of the dog-water hadith on a different axis, the horizontal $\mathrm{x}$ axis. The $\mathrm{x}$ axis allows us to measure how a particular legal outcome will influence and impact human experience in its variety.

Using the quadrants model of Islamic reasoning, we begin at an initial starting point where both the $\mathrm{x}$ and $\mathrm{y}$ values are zero $(\mathrm{o}, \mathrm{o})$, namely at the intersection of the $\mathrm{x}$ and $\mathrm{y}$ axes on the graph illustrated at the beginning of this essay. We then calculate whether a given act, in light of relevant sources, constitutes a matter along the $\mathrm{x}$ axis, the $\mathrm{y}$ axis, or both. In most cases, we will find that both axes matter, to varying degrees. Indeed, the debate among jurists may very well be captured by reference to how they emphasize the content of one

who mix with you (min al-țawāfin 'alaykum aw al-țawāfāt)," or in other words, it is a domestic animal. Mālik b. Anas, Muwațtà' i, 22. By reference to this hadīth, Ibn Rushd al-Jadd argued that "those carnivorous animals that do not mix with us in our homes carry impurities." Ibn Rushd al-Jadd, al-Muqaddimāt i, 87. By implication, carnivorous animals such as dogs that mix with us in our homes do not necessarily pollute all that they touch or lick. Ibn Rushd al-Hafīd, Bidāyat al-mujtahid i, 3o. Interestingly, Ibn Rushd al-Jadd noted that not all Mālikīs agree with this position. One group, following Ibn Wahb (d. 197/813) ignored the argument concerning the domesticity of dogs. Ibn Rushd al-Jadd, al-Muqaddimāt i, 88-9. But others such as Ibn al-Mājishūn (d. 211/827) held that rural dogs $($ badawī) pose no danger of pollution if domesticated, but urban dogs (hadarì) do. Ibn Rushd al-Jadd, al-Muqaddimāt i, 89. Of course, there is some inconsistency in holding that a domestic predatory animal does not necessarily pollute food, but does pollute a small amount of water. The answer to this may rest on other hadiths that involve animals drinking from large ponds. 
axis over another. To illustrate how these axes operate in juristic reasoning to help plot doctrinal rules in one or another quadrant, we explore various rulings concerning the dog and its impurity. Throughout, we examine the extent and degree to which the jurist's reasoning reflects concerns along the $\mathrm{x}$ and $\mathrm{y}$ axes, and how those concerns are balanced to influence how each doctrinal rule is plotted in one or another quadrant.

If dogs are impure and polluting, one might wonder why jurists would tolerate the existence of dogs at all. If canines carry impurities and endanger the wellbeing (spiritual and otherwise) of Muslims, why not simply order the execution of all dogs? This option is not entirely far-fetched, in large part because of a tradition in which the Prophet expressly commanded killing all dogs. After issuing the command, he then exempted from its application hunting dogs, herding dogs, and farming dogs. ${ }^{29}$ Some versions of the tradition include other exemptions. Other versions contain no exceptions whatsoever. In yet different versions, after the Prophet commanded the killing of dogs, he subsequently dispatched people to kill the dogs in the area around Medina. ${ }^{30}$ A review of these traditions and later doctrinal rules suggests that jurists read different normative sources (e.g., hadìth) together to create a general rule to kill canines, with exceptions for limited classes of dogs.

The Prophet's motive in killing all dogs relates to a story that states that angels do not enter homes when dogs are present. We learn from the Prophet's wife 'Â'isha that the angel Gabriel promised to visit the Prophet Muhammad at a given hour. That hour came but Gabriel did not. The Prophet, disturbed by Gabriel's absence, paced the room of 'Â'isha's house, holding a stick in one hand while slapping it into the other. At one point, the Prophet noticed to his surprise a puppy under the bed. He called out: “'̄'isha when did this dog enter here?" 'Â'isha did not know, but immediately removed the dog from the premises upon the Prophet's request. Upon doing so, Gabriel arrived. The Prophet said to him: "You promised [to meet with] me so I waited. But you did not show

29 Al-Nawawī, Sharh șaḥịh Muslim iii-iv, 176. The last category of dogs, agricultural dogs, is not found in all versions of the tradition. There are other traditions, attributed to Abu Hurayra in which this particular dog is included among those that could be owned. Al-Nawawī, Sharh șahịh Muslim ix-x, 479. 
up." Gabriel responded: “The dog that was in your house prevented me from entering. We [angels] do not enter a house which has a dog or picture in it." ${ }^{31}$ Upon learning this, the Prophet commanded all dogs to be killed. ${ }^{32}$

The theological significance associated with angels is certainly great. In the Islamic tradition the angel Gabriel is considered to be the conduit of God's revelation to the Prophet. Further, for angels to visit people in their homes might reasonably be considered a blessing. For a dog to block angels from entering one's home defines the dog as antithetical to these sacred and pure representatives of the divine. For many Muslim jurists, this episode explains why the Prophet commanded the execution of all dogs. ${ }^{33}$ Therefore, if we consider how to plot this rule, we can reasonably assert that the rule concerns one's closeness to God, something which is facilitated by one's closeness to God's representative. Consequently, given the above context, when the Prophet ordered all dogs killed, he may have infused his directive with a high y value and possibly an $\mathrm{x}$ value of zero.

With the command issued, various people went into the Medina countryside to fulfill the Prophet's order. The problem was that when the rule was put into effect the Prophet learned of its negative social implications. Two men came to the Prophet with a question. Their conversation is related by the Quranic exegete al-Qurțubī (d. 671/1272):

Oh Messenger of God, our people hunt with dogs and falcons. The dogs obtain [for us] cows, donkeys, and gazelles. From the dogs, we are able to sacrifice them [(i.e., the prey) for consumption]. But you [ordered] the killing of dogs; hence we cannot consume such food. Further, God has

31 Al-Nawawī, Sharh șaḥịh Muslim xiii-xiv, 307-9. See also Ibn Ḥanbal, Musnad vi, 163; Ibn Hajar al-'Asqalānī, Fatḥ al-bārī x, 380-1; al-Mubārakfūrī, Tuhf̣at al-aḥwadhī viii, 72-3. Incidentally, al-Mubārakfūrī wrote that the puppy in question belonged to the Prophet's grandsons, Hasan and Husayn. In another version, after the dog is removed from the house, the Prophet sprinkles water over the area where the dog was found, which some considered as positive evidence of the dog's inherent impurity. But the Mālikīs thought the sprinkling was precautionary at most. As Ibn Ḥajar al-'Asqalānī wrote, "Regarding those who do not consider the dog's essence to be impure, its place is sprinkled with water out of caution, since sprinkling is the lawful method of purification where there is doubt." Ibn Ḥajar al-'Asqalānī, Fath al-bārī x, 381. See also al-Nawawī, Sharh șaḥịh Muslim xiii-xiv, 308-10.

32 Abū Bakr b. al-'Arabī, A hkām al-Qur'ān ii, 546; al-Shawkānī, Nayl al-awțār i-ii, 38.

33 Al-Nawawī, Sharh șaḥ̣̣̄ Muslim xiii-xiv, 310; Ibn Hajar al-'Asqalānī, Fatḥ al-bārī x, 380; al-Mubārakfūrī, Tuḥfat al-aḥwadhī viii, 72. 
made impermissible improperly slaughtered animals. So what is permitted for us? ${ }^{34}$

In response to this question, wrote al-Qurțubi ${ }^{35}$ the Prophet received the following Quranic revelation:

They ask thee what is lawful to them (as food). Say: lawful unto you are (all) things good and pure: and what you have taught your trained animals [al-jawārih al-mukallibin] (to catch) in the manner directed by God: eat what they catch for you, but pronounce the name of God over it: and fear God; for God is swift in taking account (Q 5:4). ${ }^{36}$

With this verse, the Prophet permitted one to own dogs of prey, herding dogs, and farm dogs. ${ }^{37}$ Although the Prophet may have considered the original directive to have a high $\mathrm{y}$ value and likely a zero $\mathrm{x}$ value, he could not ignore the negative $\mathrm{x}$ value, once he learned this new evidence. When the consequences showed themselves, the rule had to be reconsidered in light of the negative implications for society. Taking the consequences into account, we find that while the original rule had a high $\mathrm{y}$ value, it had a negative $\mathrm{x}$ value, given its implications, thus plotting it in quadrant I. To shift it from quadrant II to quadrant $\mathrm{I}$, where the rule can have a positive $\mathrm{x}$ and $\mathrm{y}$ value, the Prophet offered exceptions to the general directive to kill all dogs, based on the Quranic verse. In doing so, he preserved the directive to kill dogs, with some exceptions, thereby controlling for the $\mathrm{x}$ value while upholding his commitment to the positive $y$ value in the original rule.

To shift the value from a negative to a positive $\mathrm{x}$ value, the Prophet construed an exception from the Quranic verse that reversed the social impact of the initial, general directive. We can glean the significance of the Quranic verse that redeems some animals (but not others) with reference to the term al-jawārih al-mukallibin, which literally means trained predatory animal. The Ḥanafĩ jurist al-Jașșāṣ (d. 370/981) concluded that 'trained predatory animal' refers to those animals that hunt on behalf of their owners. Such animals include, according to him, dogs, carnivorous animals, and birds of prey. ${ }^{38}$

\footnotetext{
34 Al-Qurțubī, al-Jāmic iii, 44.

35 Ibid.. See also Abū Bakr b. al-'Arabī, Aḥkām al-Qur'ān ii, 546; al-Jașṣāṣ, Aḥkām al-Qur'ān ii, 393; al-Ṭabarī, Tafsìr al-Ṭabarī iii, 21.

36 Ali (trans.), The glorious Kur'an.

37 Al-Qurțubī, al-Jāmic iii, 44.

38 Al-Jașșāṣ, Ahkāmm al-Qur'ān ii, 393. See also al-Qurțubī, al-Jāmi` v-vi, 45 .
} 
Al-Zamakhsharī (d. 538/1144) understood this term to refer to animals that hunt or gather (kawāsib), including dogs, tigers, and falcons. ${ }^{39}$

Consequently, while the dog constitutes a spiritual danger, it is also an important companion that ensures the well-being of people. While the spiritual danger of dogs may have led the Prophet to order the killing of all dogs, the fact that dogs can positively contribute to other aspects of human existence could not be denied, neither in fact nor in law. Instead, the example above illustrates that Islamic legal reasoning does not exist in a historical or social vacuum. Rather it is an ongoing process that reflects a multitude of calculations along different axes of analysis.

\section{$4 \quad$ Purity and Resource Management: Waste and Well-being}

An especially relevant issue that arises from the dog-water debate concerns the water left over in the container after the dog laps it up or drinks from it. Some jurists questioned whether the water lapped up by dogs can nonetheless be used for ritual purification purposes. A strict reading of Abū Hurayra's hadith suggests that any water in a container must be discarded. But does that mean water in a container of any size, regardless of how large? And if so, then what about water in a puddle, pond, or lake, from which animals often drink? Ritual purity may be important to commune with God in prayer, but at what cost to the well-being of peoples' everyday lives? Or, to put it in terms of the axes of analysis, to emphasize the imperative of ritual purity (the y value) with disregard to the social consequences of waste (the $\mathrm{x}$ value) would plot the legal outcome in quadrant II, with potentially devastating effects on social wellbeing. A dog may be considered impure; but that does not end the inquiry, given the consequences that may arise from this ruling. The dog may cause ritual impurity, but the spiritual importance of ritual (its positive y value) does not preclude delimiting the scope of the dog's impurity in other areas of human existence (along the $\mathrm{x}$ axis). Since the possibility exists that a rule requiring that one waste water in order to become ritually pure might be plotted in quadrant II (i.e., a positive $y$ value, negative $x$ value), we see that jurists contended with how to find a better balance so that both $\mathrm{x}$ and $\mathrm{y}$ values can remain positive, thus keeping the rule plotted in quadrant $\mathrm{I}$.

39 Al-Zamakhsharī, al-Kashshāf i, 594. For Ibn Kathīr, it refers to trained dogs and falcons and any bird taught to hunt. It includes predatory dogs, cheetahs or panthers, falcons, and other animals like them. Ibn Kathīr, Mukhtașar tafsīr Ibn Kathīr i, 484. 
To address this situation of potential waste, Muslim jurists considered traditions from both the Prophet and his companion 'Umar b. al-Khațāb, traditions concerning large bodies of water from which animals drink. In a hadìth, the Prophet was asked about using water from a pond between Mecca and Medina, from which predatory animals would drink. The Prophet responded: "For them [i.e., the animals] is what they drink. What remains is for us to drink, and it is pure." 40 In the second tradition, "Umar was with a riding party when they arrived at a pond. A member of the party asked the caretakers of the pond whether predatory animals drink from it. 'Umar interrupted: "Oh caretakers of the pond do not tell us. We are welcomed by the animals and the animals are welcomed by us." ${ }^{11}$ Sunni jurists relied on these traditions to shift the analysis from the impurity of animals to concerns about waste. They were no doubt aware that the issue of impurity arises in these cases, but the rules on impurity are not alone dispositive of the issue. Despite any impurity associated with the dog, jurists seemed to incorporate resource management, waste, and social well-being into their analytic concerns.

To shift the frame of analysis to waste, jurists inquired about the amount of water in a container or the size of the container itself. For many Sunni jurists, if the amount of water lapped up by a dog is large, the water is not impure, despite his lapping it up. ${ }^{42}$ Mālik b. Anas said: "Ritual purification with the excess water of a dog does not please me, where the water is of a small amount... But it is not a problem if the water is of a large quantity."43 Even jurists who generally considered the dog impure in its essence relied on quantity to limit the application of the dog-water tradition. For instance, al-Nawawi stated: "If a dog laps [up water] from a large quantity of water such that his

40 Al-Sarakhsī, Kitāb al-Mabsūṭ i-ii, 48-9; Saḥnūn, al-Mudawwana i, 6; al-Māwardī, al-Hā̄wī l-kabiri, 304.

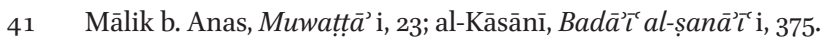

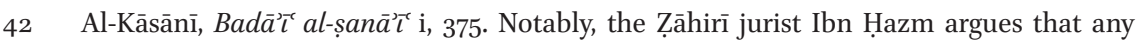
reliance upon the quantity of water at issue is an inappropriate extension of the rule. Responding to the Shāfi'is, he wrote: "Al-Shāfici said 'If the water in the container is 500 rațls, do not dump it if a dog licked from it." Ibn Hazm, however, would dump out the contents out of worshipful obedience, regardless of the quantity of water at issue. Ibn Hazm, al-Muhallā i, 123, 155 .

43 Saḥnūn, al-Mudawwana i, 6. Likewise, the Hanbalī jurist Ibn Taymiyya (d. 728/1328), relied on quantity as a central feature of his analysis. Relying on customary practices ('âdāt), Ibn Taymiyya held that the container from which a dog licks is usually small. Consequently, the dog's saliva sticks to the water and the container. Hence one must dump the water and wash the container. But if the container is large, no impurity arises. Ibn Taymiyya, Majmī' $\overline{u x}^{\mathrm{x}} 5^{21}$. 
lapping [it up] does not reduce it to [less than] two qullas, then its [lapping it up] does not render [the water] impure."44 "Qulla" is meant to convey a particular quantity of measure. The exact quantity it denotes is not clear; however, some suggest that it refers to a large jar (al-jarrah al-kabïra) or small jug (al-kuz al-ṣaghir). ${ }^{45}$ If the water is greater than two qullas, it remains pure; ${ }^{46}$ but if it is less, the water is impure. ${ }^{47}$ In such cases, the jurists balanced their concerns of impurity and waste, and were keen to plot any resulting ruling in quadrant $\mathrm{I}$, where both $\mathrm{x}$ and $\mathrm{y}$ values are positive. ${ }^{48}$

\section{From Demon Dogs to Dangerous Women: Piety, Prayer, and the Polity}

One of the more colorful dog-related traditions involves the situation in which a dog, often a black dog, passes in front of a man praying. A tradition on this point reads as follows:

44 Al-Nawawī, Sharh șaḥịh Muslim iii-iv, 177. See also Ibn Hajar al-Haytamī, al-Fatāwā i, 61, who addressed the situation in which a dog drinks from a well containing a large amount of water. Although he did not rely on the two qulla threshold, he still invoked the quantity of water as a mediating factor in the overall purity of water licked by a dog.

45 Ibn Manzūur, Lisān al-'arab xi, 288.

46 Notably, even if the amount of waters is two qullas or more, it can still become impure if one of its qualities is changed by the introduction of any external impurity. According to al-Qaffāl, although the amount of water may be greater than two qullas, if there is a change in one of the characteristics of the water (i.e., color, taste, smell), then it is impure. If there is no such change, then the water remains pure, even if an impure entity, such as a dog, makes contact with it. Al-Qaffāl, Hilyat al-'ulamā’ i, 8o. See also the Hanbalī Ibn Qayyim al-Jawziyya, I'lām al-muwaqqi'in i, 483.

47 Al-Qaffāl, Hilyat al-'ulamā’ i, 8o. There are two prevailing views among the Shâfi'is on what one must do with the water in this case. Some require the contents of the container to be dumped, and prohibit their use. Others hold that dumping the contents of the container is not obligatory (wājib) but rather preferred (mustahabb). Furthermore, the use of the water, in certain circumstances, may be permitted. Al-Māwardī, al-Hāwwi l-kabīr i, 305; al-Qaffāl, Hilyat al- ulamā’ i, 314. Nevertheless, al-Māwardī and al-Qaffāl preferred dumping the vessel's content. Al-Māwardī, al-Ḥ̄̄wì l-kabīr i, 304; al-Qaffāl, Hilyat al-'ulamā' i, 314.

48 The Isma'ili jurist al-Qāḍi l-Nu'mān discussed the case in which an animal falls into a well and dies. "If something emanating from the animal changes one of the water's characteristics [i.e., color, taste, or smell], [the water] should be avoided until the change is removed, [so that] the water becomes wholesome and obviates [the impurities] ... At that moment, it is pure." Al-Qāḍī l-Nu'mān, Da‘ẩim al-Islām i, 112-3. 
According to Abū Dharr [al-Ghifārī (d. ca. 32/652-3)], the Prophet said: "If one of you prays, he [should] lay before him a [barrier], ${ }^{49}$ such as the back half of a saddle. If there is nothing, like the back half of a saddle, in front of him, then a donkey, woman, or black dog [that passes in front of him] voids [qat? $]$ his prayer." 50

The implications of this tradition vis-à-vis the dog, let alone women, are enormous. ${ }^{51}$ The fact that a dog can invalidate one's prayer emphasizes the eschatological danger of dogs, or in other words, the need to avoid dogs in order to maintain a connection to God (a positive y value). ${ }^{52}$ Prayer is the moment when one is communicating with God; it is an intimate moment for the soul of the believer. Jurists were certainly concerned about a dog's ability to interfere with that relationship and the eschatological implications of dogs, or in other words, the dog's affect on the vertical y axis.

Yet jurists could not read this tradition solely in terms of its implication on y values. They had to devise a ruling from this tradition that did not, at the same time, adversely affect the $\mathrm{x}$ value associated with any rules governing prayer. So for instance, if we take the tradition at face value as applying to black dogs,

49 A sutra is generally an item that someone praying sets before him, "sticking it in the ground or laying it down if the ground be hard, in order that no living being or image may be the object next before him." Lane, Arabic-English lexicon i, 1304; See also Ibn Manzūr, Lisān al-'arab vi, 169 .

50 Al-Nawawī, Sharh șaḥị̣ Muslim iii-iv, 450. In another version narrated by Abū Hurayra, the color of the dog is not specified. Al-Nawawī, Sharh șaḥị Muslim iii-iv, 451; Ibn Hanbal, Musnad v, 194, 197, 202, 208; Ibn Ḥazm, Muḥallā ii, 320-6; Ibn Qayyim al-Jawziyya, I' làm al-muwaqqīin ii, 79-80; Abū Bakr b. al-'Arabī, 'Ārị̣at al-aḥwadhī i, 133. Ibn al-'Arabī remarks that al-Tirmidhī considered this tradition to be hasan șaḥ̄h, a designation that is perhaps unique to al-Tirmidhī. Abou El Fadl, The authoritative and the authoritarian 47-8.

$5^{1}$ Ibn Ḥazm, al-Muḥallā ii, 322. See also Abū Bakr b. al-'Arabī, 'Ārị̣at al-aḥwadhì ii, 134. As one can imagine, the fact that women can negate a man's prayer in the same fashion as a dog or a donkey, raises serious concerns at the possible chauvinism implicit in this tradition. Interestingly, this possibility was not necessarily lost on the jurists themselves. This tradition raises gender concerns over the association between animals and women. Whether Islamic theology supports such an assertion, or whether this tradition is the result of chauvinist tendencies among the narrators requires a separate study. See Abou El Fadl, The authoritative and the authoritarian 71, note 60, who suggests that discourses on women prostrating to their husbands are "largely chauvinistic, and possibly immoral." For an important recent study on gender, ethics and Islam, see Ali, Sexual ethics.

$5^{2}$ Notably, there are some versions that do not specify black dogs, and rather consider all dogs equally capable of voiding one's prayer. See for example, Ibn Hazm, Muhallā ii, 321; Ibn Hanbal, Musnad vi, 99. 
we might ask whether this tradition adversely impacts rules that allow the limited ownership of dogs. Drawing upon the Prophet's exemption of certain dogs from the general command to execute all dogs, the Shāfi'i jurist al-Nawawī recognized that, in some cases, people should be permitted to own dogs. Those cases are characterized in terms of an individuals' needs and necessities, those which ensure his well-being. Al-Nawawī wrote:

Our companions [i.e., Shāfici jurists] and others agree that it is prohibited to own dogs for reasons other than need (hajaja), such as owning a dog for the pleasure of its appearance, or out of pride. This is prohibited, without debate. As for the need (hāja) for which it is permissible to own a dog, the prophetic tradition includes an exception for any one of three dogs: farming, herding, and hunting. This is permitted without debate. ${ }^{53}$

The reference to hāja is a crucial indication that what is at stake in the prophetic exception to canine execution is an acknowledgment that dogs play an important role in certain activities. Need does not include the joy of a dog's companionship; rather need captures the functional role of a dog in ensuring the success of certain industries in society - industries upon which all of society potentially depends. ${ }^{54}$

But when read alongside the black dog tradition, jurists addressed whether the dogs that can be owned for agricultural purposes must be any color other than black. On the one hand, the black dog is deemed to be an eschatological threat. For example, in most accounts of the black dog tradition, an additional section is added which explains the specification of the color. Abū Dharr al-Ghifārī is asked: "Oh Abū Dharr, what is the [difference] between black dogs, red dogs, and yellow dogs?" Abū Dharr responded: "I asked [that of] the messenger of God, just as you are asking me. He said: 'The black dog is a devil (shayțān).""55 The black dog that voids prayer is no simple dog. It is an evil spirit, a demon dog of hell. ${ }^{56}$

53 Al-Nawawī, Sharh șaḥịh Muslim iii-iv, 177.

54 Ibid., iii-iv, 176-7; ix-x, 479-8o.

55 Ibid., iii-iv, 450; Ibn Hanbal, Musnad v, 194, 197. See also Abū Bakr b. al-AArabī, 'Ārị̣t al-ahwwadhī ii, 133 for reference to the black dog.

56 Incidentally, the association of the dog (particularly the black dog) with the devil is not unique to the medieval Islamic world. European folklore abounds with numerous references to demons and devils in dog form. Quite often, such demon dogs take the form of a black dog. For example, in Cambridge, Essex, Suffolk, and Norfolk the black dog ghost is: "frequently one-eyed, haunts coasts, fens, roads, and churchyards, and is always ominous... In the Isle of Man, there is a vague ghost, sometimes in the form of a black dog, 
The Islamic legal tradition's association of the black dog with the devil only reemphasizes the dog's negative value. More than simply being a source of filth and impurity, it is arguably a locus of evil. On the other hand, this is not to deny the useful social purposes that dogs can serve. How must the jurist plot the ruling? To plot the rule in quadrant I, what sort of factors might the jurist take into account? There was, as one might expect, considerable disagreement, especially because limiting ownership of dogs to those that are not black may or may not put a severe burden on the interests of farmers and agricultural laborers. Al-Nawawī tells us, for instance, that some jurists prohibited owning black hunting dogs. Rather such dogs must be killed since they are devils. ${ }^{57}$ But he also related that al-Shāfi'i (d. 204/820), Mālik b. Anas, and the majority of scholars permit one to own black hunting dogs. Al-Nawawī then noted: "The intent of the tradition [about dogs as devils] is not to displace [black dogs] from the dog species entirely." 58 While the tradition on black dogs might appear inflexible and unforgiving, the juristic debate on canine exceptions suggests that the black dog tradition had more bark than bite. Despite the negative attitude toward black dogs, jurists could not ignore the fact that dogs, black or otherwise, cannot be classified in absolute terms, whether as a pure eschatological threat or as a pure social benefit. Yet in plotting rules of law in

that haunts roads; and in Guernsey, black dogs attack wayfarers during the Twelve Days of Christmas." Brown, The black dog 176. Ethel Rudkin, writing in 1938, begins her article on the black dog by noting that the "Black Dog walks in Lincolnshire still; and there are a number of living people who have seen him, heard him, and even felt him." Rudkin, The black dog 111. When the black dog appears, it may have two heads or none at all. Its eyes may be as big as saucers. Brown, The black dog 180-1. Rudkin's research also indicates that in the British town of Northrope, "there is a Black Dog that haunts the churchyard, known as Barguest." Rudkin, The black dog 117. Sometimes the black dog is not necessarily evil. Nevertheless, its common association with evil is undeniable, especially in the regions of Scandinavia and Germany. Brown, The black dog 188 . It is perhaps not entirely surprising that the black dog would be considered a devil given certain natural circumstances. In her study of the devil in dog form in European folklore, Barbara Allen Woods provides a possible explanation for why black dogs in particular might be associated with evil. She writes: "There is nothing extraordinary or mythical about such an incident. On the contrary it is entirely natural that a dog should be out trotting the deserted streets and paths. It is not even beyond credulity that such an animal would appear black in the darkness, or that its eyes, if they were caught in a faint ray of light, would appear large and fiery ... Yet, any or all of these normal characteristics can seem positively uncanny, especially when observed under eerie circumstances or in an anxious state of mind." Woods, The Devil in dog form 33 .

57 Al-Nawawī, Sharh șaḥịh Muslim ix-x, 480; xiii, 76.

58 Ibid. 
light of these types of concerns, we can observe the reliance on competing axes of analysis.

Indeed, those axes pose significant challenges when considering the indirect implications of the dog-prayer tradition on the status of women. By juxtaposing women with the black dog, this tradition suggests that the dangers of the black dog's impurity and evil apply to women as well. In fact, some Muslim jurists, relying on this tradition, deemed a man's prayer void if a donkey, black dog, or woman passes in front of him while he prays. ${ }^{59}$ Others, however, omit the donkey and women from the tradition, and instead held that only the dog negates one's prayer. They argued that if a woman or donkey passes in front of a man praying, his prayer is not void, although his concentration in prayer may be interrupted. ${ }^{60}$ This reading dissociates women from dogs, but maintains the link between women and donkeys. Although the animal comparators shift, women remain equated with beasts of burden.

The implications of this tradition were certainly not lost on the jurists. For instance, Ibn Hazm reported that 'Â'isha complained about the implications of this hadith. She said: "You [men] put us [women] in the position of dogs and donkeys. Only the following negate prayer: dogs, donkeys, and cats." ${ }^{\text {. } 1 \text { As }}$ mentioned above, some jurists even omit "women" from the tradition entirely. This exclusion is based on traditions from the Prophet's wife, 'Â'isha. It was reported that she was lying down in front of the Prophet while he was praying. If the tradition equating dogs and women were historically accurate, then the Prophet's prayer would have been invalidated by his wife's position in front of him as he prayed. But the Prophet continued to pray undisturbed. Only later when she decided to sit upright did the Prophet move, thus suggesting that his prayer was disturbed. This particular set of events prompted the Andalusian jurist, Ibn Hazm (d. 456/1064), to suggest that as long as 'Â'isha was lying down in front of the Prophet, no damage was done. But once she sat upright, she obstructed his prayer prompting him to move, and presumably restart his

59 Al-Nawawī, Sharh șaḥịh Muslim iii-iv, 450; Abū Bakr b. al-'Arabī, 'Ārị̣at al-aḥwadhī ii, 1334, noted that the Companions Abū Dharr al-Ghifārī, Ibn 'Umar, Anas, and al-Ḥasan were of this opinion; Ibn Hazm, Muhallā ii, 320, adopted the general reading of the tradition, however he made an exception for women who are lying down as if asleep, on the basis of narrations from the Prophet's wife, 'Ā'isha. These traditions will be discussed below.

6o Al-Nawawī, Sharh șaḥ̄ḥ Muslim iii-iv, 450; Abū Bakr b. al-'Arabī, Āriḍat al-aḥwadhī ii, 133 .

61 Ibn Hazm, Muhallā ii, 324. Another view of this tradition narrows its meaning to apply only to menstruating women. Abū Bakr b. al-'Arabī challenged this position as being based on weak evidence. Abū Bakr b. al-'Arabī, 'Ārị̣tat al-aḥwadhī ii, 134; Ibn Hazm, Muhallā ii, 324. 
prayer. ${ }^{62}$ The rationale for Ibn Hazm's distinction is less important here than the fact that it has nothing to do with 'Ā'isha as a woman.

Another reading goes so far as to redeem the dog in order to undermine the social implications of the dog-prayer tradition entirely. That reading holds that nothing negates one's prayer. Instead, the black dog tradition relates to the loss of one's concentration. This argument hinges on the way in which the particular Arabic term qat ${ }^{\prime}$ is interpreted. The word $q a t^{c}$ means to cut or sever, and could connote the voidance of the prayer in this tradition. But many jurists argued that what is "cut" is not the prayer itself, but rather the concentration of the person praying. ${ }^{63}$ At most, the tradition emphasizes the need to concentrate on prayer and take pains to avoid distractions in prayer when possible. Instead of rendering the animal or woman a roving eschatological danger that can invalidate one's prayer, the majority of jurists put the onus on the person praying to pray in an environment where he can concentrate. In doing so, they remained committed to understanding the tradition in terms of its eschatological significance (its y value), without creating negative social implications (its $\mathrm{x}$ value). Thus, they saw the hadith as a warning that those who pray should concentrate when convening with their Lord. In this sense, they plotted the resulting rule using a positive y axis while delimiting its social impact almost entirely (i.e., a zero x value).

The multiple interpretations about the black dog tradition illustrate that, despite source-texts providing an apparently clear statement of a rule, the effect of any such rule must be mediated in light of everyday life. By invalidating prayers, dogs are in bad standing with those who are concerned with their eschatological well-being, presumably any Muslim who seeks to commune with God. For such otherworldly-minded people, the danger the dog poses may constitute sufficient justification for a hostile stand against the dog in worldly and mundane affairs. The relationship between the eschatological and the sociological seems evident from the debate among jurists about whether

\footnotetext{
62 Ibn Hazm, al-Muhallā ii, 322.

63 Al-Nawawī, Sharḥ șaḥị̣ Muslim iii-iv, 450; Abū Bakr b. al-'Arabī, 'Ārị̣at al-aḥwadhì ii, 134. According to al-Nawawī, some held the tradition to be abrogated by another that states: "Nothing negates one's prayer. Block whatever you can [from crossing]." Al-Nawawī, Sharh șaḥih Muslim iii-iv, 450. Ibn al-'Arabī held that prayers are not voided, given another tradition in which Ibn 'Abbās narrated as follows: "I was sitting behind [someone] on a donkey when we came upon the Prophet as he and his companions were praying at Mina. We descended from the donkey and entered the prayer line. The donkey passed in front of them, but their prayer was not negated." According to Ibn al-'Arabī this tradition has two possible explanations: first, nothing negates prayer; second, the prayer leader's sutra is a sutra for the entire congregation. Abū Bakr b. al-'Arabī, 'Āridat al-aḥwadhī ii, 132-3.
} 
black dogs can be owned, or whether they should constitute a special category of dogs, one that is vulnerable to the prophetic command to kill all dogs. The social implications of the eschatological concern are also evident in the way jurists considered the juxtaposition of dogs and women. Not only might black dogs be vulnerable, women might also be ostracized out of concern for their eschatological threat. To avoid such adverse social implications for both dogs and women, the majority position returns to the context of eschatology by reading the black dog tradition as a comment on the responsibility of those who pray. In doing so, the locus of danger shifts from the dog and woman to the individual in prayer who is not fully focused on what he or she is doing. Between the minority and majority positions we find a focus on eschatology, a topic that may fit uneasily with modern conceptions of legal ordering. But as suggested in this study, the eschatological component in these traditions animates broad-ranging concerns about what the polluting dog might mean to Muslims working in the fields, drinking from ponds, or praying in crowded areas.

\section{Conclusion}

The dog-water tradition is one among many dog-related traditions that contribute to a process of legal reasoning that cannot rely on a neat divide between the "legal" and the "moral," without at the same time controlling for the institutional assumptions that give the law/morality dichotomy salience and significance. This essay relies on a quadrant model that posits two axes of analysis, the here and the hereafter, as elemental to Muslim jurists' reasoning about the law. These two axes invoke ideas that may echo sentiments associated with the law/morality distinction; but the two axes also control for the unstated assumptions that may give the law/morality conceptual dichotomy its significance and poignancy. Muslim jurists recognized that the pollution of dogs in matters of ritual not only implicates eschatological concerns; the pollution of dogs for ritual purposes could also have serious implications on mundane matters that have little or nothing to do with ritual practice, and thereby have limited eschatological significance. The dog may have been viewed as a source of impurity that might prevent one from communing with God in prayer; but that view did not end the inquiry. For many jurists, that view constituted the beginning of an analytic process that contended with the complexity of human needs and lived experience. That process could not ignore the interests associated with what might be considered in contemporary parlance 'moral,' if not 'religious' and thereby private - nor could it ignore those interests that 
might be considered 'legal.' However, to rely upon the dichotomy between the 'legal' and the 'moral' imposes a modern bifurcation that does not adequately explain what Muslim jurists were doing when working with competing sourcetexts, whether Quranic verses or hadith texts. Adopting the quadrants model of analysis allows us to appreciate that the legitimacy and authority of any doctrinal rule depends on how it is plotted in light of two axes of analysis, one which is concerned with the individual's relationship with God and the other that is concerned with individual experience and social well-being. In other words, the jurists plotted doctrinal rules in terms of interests that pertain to both the here and the hereafter. By plotting a doctrinal rule in terms of both the here and the hereafter, I do not mean to distinguish the Islamic model of analysis from other modes of legal interpretation. Indeed, the rationales for the various rules noted above are highly rational and reasonable; their rationality is clear when we appreciate and understand the frame of reference or background factor that makes juristic reasoning intelligible. The dichotomy between law and morality is certainly an important dichotomy as it pertains to contemporary legal theory in the modern state. But it does not fully capture the framework that animated Muslim jurists in the past, whose presumptions about political society, and its relationship to the law, were different from ours today. The quadrants model shows how Muslim jurists reasoned and reached doctrinal outcomes in light of concerns that are not easily captured by contemporary philosophies of law, although that does not mean such concerns are unintelligible or irrational. Each doctrinal rule arises from a complex process of legal reasoning amidst axes of analysis that reflect fundamental concerns that lie at the heart of the Islamic legal worldview.

But why offer the quadrants model at all? In a world coming to terms with the growing significance of religion in the public sphere, ${ }^{64}$ we cannot ignore

64 The increased relevance of religion (and in particular Islam) to debates about liberal governance and the public sphere in North America and Europe is evident in increasing scholarly attention to the issue of religion and the public sphere. For important scholarship on the issue, see Casanova, Public religions in the modern world; Casanova, Public religions revisited. Increasingly universities in North America and Europe are initiating centers devoted to the study of religion in the public sphere. See for instance, the University of Toronto's Religion in the public sphere (http://www.chass.utoronto.ca/rps/); The Baldy Center for Law and Social Policy, at the State University of New York Buffalo sponsors working groups on Law and Religion and Law, Religion and Culture (http://www .law.buffalo.edu/BALDYCENTER/research.htm); The University of Exeter in the United Kingdom is the home of the European Muslim Research Centre (http://centres.exeter. ac.uk/emrc/). In terms of policy development, Quebec's Reasonable Accommodation Commission, led by Charles Taylor and Gérard Bouchard, illustrates that even 
the imperative to grapple with the difficult challenge of living together amidst our differences. All too often, that challenge is met with political rhetoric and polemics, leading to public policies that not only perpetuate stereotypes, but also marginalize, if not demonize, those who are deemed different. This tendency was certainly evident in the 2005 debate in Ontario, Canada that concerned shari ${ }^{-} a$-based family law arbitration, ${ }^{65}$ and it took center stage again in 2010 when the Swiss constitution was amended by a popular referendum to ban the erection of minarets for mosques in the country. ${ }^{66}$

Yet, this polemic is confirmed by stories of Muslims who adhere to an uncompromising, inflexible, and at times an oppressive version of sharía. Such stories include, for instance, Muslim taxi drivers who refuse to drive blind passengers accompanied by seeing-eye dogs, on the basis that dogs are impure according to Islamic law. ${ }^{67}$ Such cases are often described in liberal constitutional terms as examples of rights in conflict: the rights of the disabled versus the rights of the religious adherent.

Resolving such conflicts is no easy matter. But that difficulty is not unique to a liberal constitutional system of law and order; nor will it always find an amenable resolution in liberal, constitutional terms of analysis and reference. For instance, such stories may situate the conflict in terms of a distinction and division between the public and the private, the secular and religious, the church and the state, and the law and morality.

The quadrants model developed above offers additional analytic terms to characterize such conflicts. These terms, described above as axes of analysis, take into account the dynamics of Islamic legal reasoning, without precluding the possibility of dialogue between the animating principles of different legal systems. Furthermore, the quadrants model has an important consequence: it counters the tendency to place Islamic doctrinal rules in contemporary categories such as the 'religious' or even the 'cultural.' Too often such terms are code for the 'irrational,' and thereby place debates about Islamic law and its significance for Muslims outside the realm of conscientious reasoned deliberation about law, order, and good governance. ${ }^{68}$ The quadrants model, therefore, offers a way of unpacking the significance of a given legal rule by emphasizing

governments are not immune from contending with the place of religion in the public sphere (for official website, see http://www.accommodements.qc.ca/index-en.html).

65 For a commentary on the tenor and tone of the debate, and its marginalizing implications, see Bakht, Muslim barbarians 67-82.

66 Caldwell, No minarets, please 9; Nurrohman, A lesson to draw 7.

67 Brothers, Cabbie refused ride to guide dog B2; Saleh, Dirty dogs i, 27.

68 Brown, Regulating aversion 152-4. 
the competing interests at stake. It shifts the focus from debating about the authoritative hold of a given rule, to appreciating and accounting for the rational inputs that made the rule intelligible in a given period or era.

\section{Bibliography}

Abou El Fadl, Kh., The authoritative and the authoritarian in Islamic discourses: A contemporary case study, Austin $1997^{2}$.

— Dogs in the Islamic tradition, in B. Taylor (ed.), The encyclopedia of religion and nature, ii, Briston 2005, 498-500.

— The lord of the essence: A fatwa on dogs, in Kh. Abou El Fadl, The search for beauty in Islam: A conference of the books, Oxford 2006, 316-30.

Abu-Saud, M., Concept of Islam, Indianapolis 1983.

Ali, K., Sexual ethics and Islam: Feminist reflections on Qur'an, Hadith and jurisprudence, Oxford 2006.

Ali, Y.A. (trans.), The glorious Kur'an, Riyadh $1938^{3}$.

Atiyah, P.S. and R.S. Summers, Form and substance in Anglo-American law: A comparative study of legal reasoning, legal theory, and legal institutions, Oxford 1991.

Bakht, N., Were Muslim barbarians really knocking on the gates of Ontario? The religious arbitration controversy, in Ottawa Law Review 2006 (2006), 67-82.

Brothers, P., Cabbie refused ride to guide dog; Rights issue stymies city; Blind woman's dog 'impure,' in The Cincinnati (Ohio) Enquirer (April 3, 1999), B2.

Brown, T., The black dog, in Folklore 69 (September 1958), 175-92.

Brown, W., Regulating aversion: Tolerance in the age of identity and empire, Princeton, NJ 2006.

Caldwell, Ch., No minarets, please, in The Weekly Standard 15.3 (December 14, 2009), 9.

Canard, M., Ḥākim Bi-Amr Allāh, in $E I^{2}$, iii, $76-82$.

Cane, P., Taking law seriously: Starting points of the Hart/Devlin debate, in The Journal of Ethics 10 (2006), 21-51.

Casanova, J., Public religions in the modern world, Chicago 1994.

—, Public religions revisited, in H. de Vries (ed.), Religion: Beyond a concept, New York 2008, 101-19.

Coulson, N.J., Conflicts and tensions in Islamic jurisprudence, Chicago 1969.

al-Dhahabī, Shams al-Dīn, Siyar a làm al-nubalā', ed. S. al-Arna'ūt and A. al-Būshī, Beirut $1986^{4}$.

Dworkin, R., Lord Devlin and the enforcement of morals, in The Yale Law Journal 75.6 (May 1966), 986-1005.

Emon, A.M., Huqūq Allah and ḥuqūq al-ibād: A legal heuristic for a natural rights regime, in Islamic Law and Society 13.3 (2006), 325-91. 
Hallaq, W., Sharīa: Theory, practice, transformations, Cambridge 2009.

Ibn al-'Arabī, Abū Bakr, Ahkām al-Qur'ān, Beirut n.d.

- Árị̂tat al-ahwwadhī bi-sharh șaḥ̆h al-Tirmidhì, Beirut 1997.

Ibn Ḥajar al-'Asqalānī, Fath al-bārī bi-sharh șaḥ̄h al-Bukhārī, ed. Q. Muhibb al-Dīn al-Khațīb, Cairo 1407 AH.

Ibn Ḥajar al-Haytamī, A., al-Fatāwā l-kubrā l-fiqhiyya, ed. 'A. al-Fākihī al-Makkī and 'A.

'Abd al-Raḥmān, Beirut 1997.

Ibn Ḥanbal, A., Musnad al-imām Ạ̣mad b. Hanbal, ed. S. al-Majzūb, Beirut 1993.

Ibn Ḥazm, al-Muhallā bi-l-athār, ed. 'A. Sulaymān al-Bandārī, Beirut n.d.

Ibn Kathīr, Mukhtașar tafsìr Ibn Kathïr, ed. M. al-'Aban, Beirut 1981.

Ibn Manzūur, Lisān al-'arab, ed. A. Shīrī, Beirut 1988.

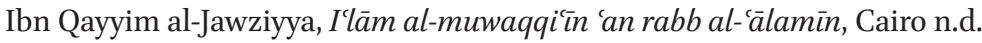

Ibn Rushd al-Hafīd, Bidāyat al-mujtahid wa-nihāyat al-muqtașid, ed. M. al-Bābī al-Ḥalabī, Cairo 1981.

Ibn Rushd al-Jadd, al-Muqaddimāt al-mumahhidāt, ed. M. Ḥujjī, Beirut 1988.

Ibn Taymiyya, Majmū'fatāwā, ed. M. 'Abd al-Raḥmān, n.p., n.d.

al-Jașsāạ, Abū Bakr, Aḥkām al-Qurāàn, Beirut n.d.

Kamali, M.H., Principles of Islamic jurisprudence, Cambridge 2003.

, Shariah law: An introduction, Oxford 2008.

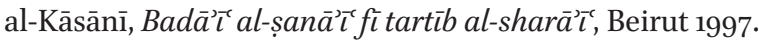

Lane, E.W., Arabic-English lexicon, Cambridge 1984.

Mālik b. Anas, Muwatțā', Cairo n.d.

al-Māwardī, Abū l-Ḥasan 'A., al-Hāwō̄ l-kabìr: Sharh mukhtaṣar al-muznā, Beirut 1994.

Moaddel, M. and K. Talatoff, Contemporary debates in Islam: An anthology of modernist and fundamentalist thought, New York 2000.

al-Mubārakfūrī, M. 'Abd al-Raḥmān, Tuhfat al-ahwadhì bi-sharh jāmi' al-Tirmidhī, Beirut n.d.

al-Nawawī, Sharh șaḥịh Muslim, Beirut 1996.

Nurrohman, B., A lesson to draw from the Swiss ban on minarets, in The Jakarta Post (15 December 2009), 7 .

al-Qāḍī al-Nu'mān, Dacāìm al-Islām wa-dhikr al-halāl wa-l-ḥarām wa-l-qaḍāyā wa-lahkām, ed. A. 'Alī Asghar Fīdī, Cairo 1963.

al-Qaffāl, Abū Bakr M., Hilyatal-'ulamä’f'ma'rifatmadhhab al-fuqahä', ed. Y. Darādkah, Amman 1988.

al-Qurțubī, Abū Bakr, al-Jāmic li-ạ̣kām al-Qur'ān, Beirut 1993.

Rudkin, E.H., The black dog, in Folklore 49 (June 1938), 111-31.

Sahnūn, al-Mudawwana al-kubrā, Cairo n.d.

Saleh, L., Dirty dogs, taxi drivers and a clash of faith, in The Daily Telegraph (12 October 2006) i, 27 .

al-Sarakhsī, Shams al-Dīn, Kitāb al-Mabsūț, Beirut 1993. 
al-Shāfi ī̄, M. Ibn Idrīs, Kitāb al-Umm, Beirut 1990.

al-Shawkānī, M. Ibn 'Alī, Nayl al-awțār sharh mințaqā al-akhbār, Cairo n.d.

al-Ṭabarī, M., Tafš̀r al-Ṭabarì: Jāmi' al-bayān fì tafsìr al-Qur'ān, ed. B. 'Awwād Ma'ruf and 'A.F. al-Harastānī, Beirut 1994.

Wensinck, A.J. [with A.K. Reinhart], Tayammum, in $E I^{2}$, x, 399-400.

Woods, B.A., The Devil in dog form: A partial type-index of Devil legends, Berkeley 1959.

al-Zamakhsharī, al-Kashshāf 'an haqāì al-tanzìl wa-'uyūn al-aqawïl fì wujūh al-ta’wül, Beirut n.d.

al-Ziriklī, al-A'āam: Qāmūs tarājim li-ashhar al-rijāl wa-l-nisä' min al-Arab wa-lmuta'arribin wa-l-mustashriqin, Beirut 1997. 